Human and Animal Health

Vol.59: e16150085, January-December 2016 http://dx.doi.org/10.1590/1678-4324-2016150085 ISSN 1678-4324 Online Edition

\title{
Investigation of the Acute Effects of Dry Extract of Glycine Max on Postprandial Glycemia in Rats
}

\author{
Patrícia Batista Travassos ${ }^{1}$, Vanessa Rodrigues Vilela ${ }^{1}$, Marina Masetto Antunes ${ }^{1}$, Roberto \\ Barbosa Bazotte ${ }^{1 *}$. \\ ${ }^{1}$ Universidade Estadual de Maringá, Departamento de Farmacologia e Terapêuticos, Maringá, Paraná, Brasil.
}

\begin{abstract}
The acute effects of Glycine max (GM) on post prandial glycemia (PPG) in male Wistar rats were investigated. All substances were orally administered by gavage in overnight fasted animals. The elevation of PPG promoted by starch $(1 \mathrm{~g} / \mathrm{kg})$ was prevented by $\mathrm{GM}(2.5 \mathrm{mg} / \mathrm{kg}, 5.0 \mathrm{mg} / \mathrm{kg}, 7.5 \mathrm{mg} / \mathrm{kg}, 10.0 \mathrm{mg} / \mathrm{kg}$, and $100.0 \mathrm{mg} / \mathrm{kg})$. In conclusion $\mathrm{GM}$ showed potential antidiabetic effect.
\end{abstract}

Key Words: Glycine max, soy, diabetes, acarbose, phytotherapy, post prandial glycemia.

*Authors for correspondence: rbbazotte@uem.br 


\section{INTRODUCTION}

The well-established beneficial effects on metabolism of extracts from soy have been attributed to the isoflavones ${ }^{1-5}$. In agreement with this affirmation we previously demonstrated ${ }^{6}$ activation of peroxisome proliferator-activated receptors $\alpha$ by using a methanolic fraction from soybean seeds rich in isoflavones (daidzin, glycitin, genistin, daidzein, malonylglycitin, malonylgenistin, genistein, glycitein, and malonyldaidzin).

In addition, several studies reported antidiabetic properties of isoflavones from soy, not only in preclinical models $\mathrm{s}^{7,8}$ but also in humans $\mathrm{s}^{9,10}$.

The mechanisms by which isoflavones from soy produce antidiabetic effects include: antioxidant and anti-inflammatory properties ${ }^{8}$ protection of beta cells $^{11}$, and stimulation of insulin release ${ }^{12}$.

However, there are few studies supporting that this herbal preparations could show acute beneficial effect in diabetes ${ }^{13}$. Moreover, considering that genistein, the main isoflavone present in the soy ${ }^{14}$ inhibits alpha-glucosidade ${ }^{15}$, the possibility of an acute effect of extracts of GM on post prandial glycemia should be investigated. Furthermore, there is no dearth of reports evaluating if the inhibition of alpha-glucosidase has pharmacological significance in vivo conditions.

Thus, the present study was carried out to verify if the isoflavones from soy would show acute effects on postprandial glycemia.

\section{MATERIALS AND METHODS}

PLANT MATERIALS: Capsules (Soyfemme ${ }^{\circledR}$ from Aché Laboratories - Guarulhos, SP, Brazil) containing Isoflavones (40\%) from dried extracts of Glycine max (L.) Merr (GM) were used. Immediately before the administration, the contents of the capsules were removed and dissolved in water.

EXPERIMENTAL PROCEDURES: One hundred and thirty male Wistar adult rats (Rattus norvegicus) weighing $250-300 \mathrm{~g}$ were used. The rats were maintained under controlled temperature $\left(23^{\circ} \mathrm{C}\right)$ and photoperiod (12 h light/12 h dark). All animals received free access to standard commercial laboratory diet (Nuvilab®, Curitiba, PR, Brazil). The manipulation of the animals followed the Brazilian animal protection law. All substances were orally administered through a gastric tube (gavage) in overnight (15-h) fasted rats and blood was collected by decapitation for glucose evaluation ${ }^{16}$.
Acute effect of soluble starch $(1000 \mathrm{mg} / \mathrm{kg})$ on glycemia. Glycemia was measured at 0 (baseline values), 5, 10, 15, 20, 30 and $60 \mathrm{~min}$ after the administration of soluble starch. We chose the dose of soluble starch on the basis of a previous study ${ }^{17}$. The results are presented in the Figure 1.

Acute effect of acarbose $(0.1 \mathrm{mg} / \mathrm{kg}, 1.0 \mathrm{mg} / \mathrm{kg}$ or $10.0 \mathrm{mg} / \mathrm{kg}$ ) on the elevation of glycemia after the administration of soluble starch $(1000 \mathrm{mg} / \mathrm{kg})$. Glycemia was measured $30 \mathrm{~min}$ after the simultaneous administration of soluble starch plus acarbose $(0.1 \mathrm{mg} / \mathrm{kg}, 1.0 \mathrm{mg} / \mathrm{kg}$ or $10.0 \mathrm{mg} / \mathrm{kg})$. The control group received only vehicle. Furthermore, an additional control group which received simultaneous administration of vehicle plus soluble starch was included. The results are showed in the Figure 2.

Acute effect of GM $(2.5 \mathrm{mg} / \mathrm{kg}, 5.0 \mathrm{mg} / \mathrm{kg}, 7.5$ $\mathrm{mg} / \mathrm{kg}$ or $10.0 \mathrm{mg} / \mathrm{kg}$ ) on the elevation of glycemia after the administration of soluble starch (1000 $\mathbf{m g} / \mathbf{k g}$ ). Glycemia was measured $30 \mathrm{~min}$ after the simultaneous administration of soluble starch plus GM $(2.5 \mathrm{mg} / \mathrm{kg}, 5.0 \mathrm{mg} / \mathrm{kg}, 7.5 \mathrm{mg} / \mathrm{kg}$ or 10.0 $\mathrm{mg} / \mathrm{kg}$ ). The control group received only vehicle. The positive control group received simultaneous administration of soluble starch plus acarbose (10 $\mathrm{mg} / \mathrm{kg}$ ). Furthermore, an additional control group which received simultaneous administration of vehicle plus soluble starch was included. The results are showed in the Figure 3A.

Acute effect of GM $(0.1 \mathrm{mg} / \mathrm{kg}, 1.0 \mathrm{mg} / \mathrm{kg}$ or 100.0 $\mathrm{mg} / \mathrm{kg}$ ) on the elevation of glycemia after the administration of soluble starch $(1000 \mathrm{mg} / \mathrm{kg})$. Glycemia was measured $30 \mathrm{~min}$ after the simultaneous administration of soluble starch plus GM $(0.1 \mathrm{mg} / \mathrm{kg}, 1.0 \mathrm{mg} / \mathrm{kg}$, or $100.0 \mathrm{mg} / \mathrm{kg})$. The control group received only vehicle. The positive control group received simultaneous administration of soluble starch plus acarbose $(10 \mathrm{mg} / \mathrm{kg})$. Furthermore, an additional control group that received simultaneous administration of vehicle plus soluble starch was included. The results are presented in the Figure 3B.

STATISTICAL ANALYSIS: The results are reported as means \pm standard error of the means (SEM). Significance of differences between the groups was evaluated by Newman-Keuls multiple comparison test. A 95\% level of confidence $(\mathrm{P}<0.05)$ was accepted for all comparisons. 


\section{RESULTS}

In the first set of experiments, the acute effect of oral administration of soluble starch on glycemia was investigated. As shown in Figure 1, elevation $(\mathrm{P}<0.05)$ of glycemia was observed from $15 \mathrm{~min}$ and this difference was maintained $60 \mathrm{~min}$ and $120 \mathrm{~min}$ (not showed) later. Because increased $(\mathrm{P}<0.05)$ blood glucose was well established $30 \mathrm{~min}$ after the administration of soluble starch this time was used in the following experiments.

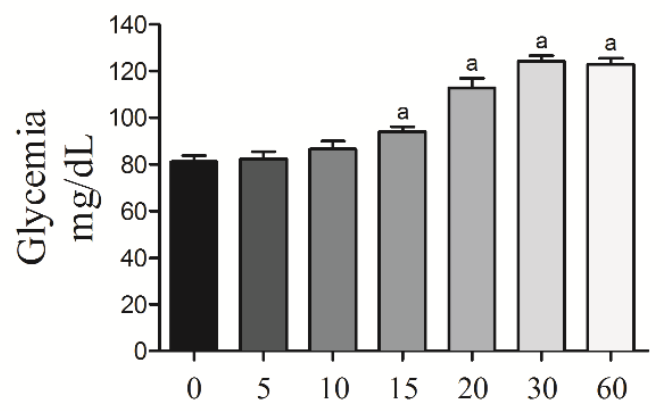

Figure 1. Effect of the acute administration (oral gavage) of soluble starch $1000 \mathrm{mg} / \mathrm{kg}$ (SS) on glycemia in 15-h fasted rats. The blood glucose concentrations were evaluated at $0,5,10,15,20,30$ and $60 \mathrm{~min}$ after SS administration. The results are presented as mean \pm standard error of the mean. $n=5$ for each time. NewmanKeuls multiple comparison test. ${ }^{\mathrm{a}} \mathrm{p}<0.05$ for comparisons between $0 \mathrm{~min} v s$. $10 \mathrm{~min}, 15 \mathrm{~min}, 20 \mathrm{~min}, 30 \mathrm{~min}$ and 60 $\min$.

In the second set of experiments, the acute effect of increasing doses of acarbose on the elevation of glycemia promoted by the administration of soluble starch was evaluated. As shown in Figure 2, the dose of $1.0 \mathrm{mg} / \mathrm{kg}$ and $10 \mathrm{mg} / \mathrm{kg}$ impair $(\mathrm{P}<0.05)$ the elevation of glycemia promoted by soluble starch.

Considering that acarbose $(10 \mathrm{mg} / \mathrm{kg})$ impaired the elevation of glycemia promoted by the administration of soluble starch this dose was used in the following experiments.

In the third set of experiments, the acute effect of increasing doses of GM on the elevation of glycemia promoted by the administration of soluble starch was evaluated. As shown in Figure 3A, the doses of 2.5 $\mathrm{mg} / \mathrm{kg}, 5.0 \mathrm{mg} / \mathrm{kg}, 7.5 \mathrm{mg} / \mathrm{kg}$, and $10.0 \mathrm{mg} / \mathrm{kg}$ decrease $(\mathrm{P}<0.05)$ the intensity of elevation of glycemia promoted by soluble starch.

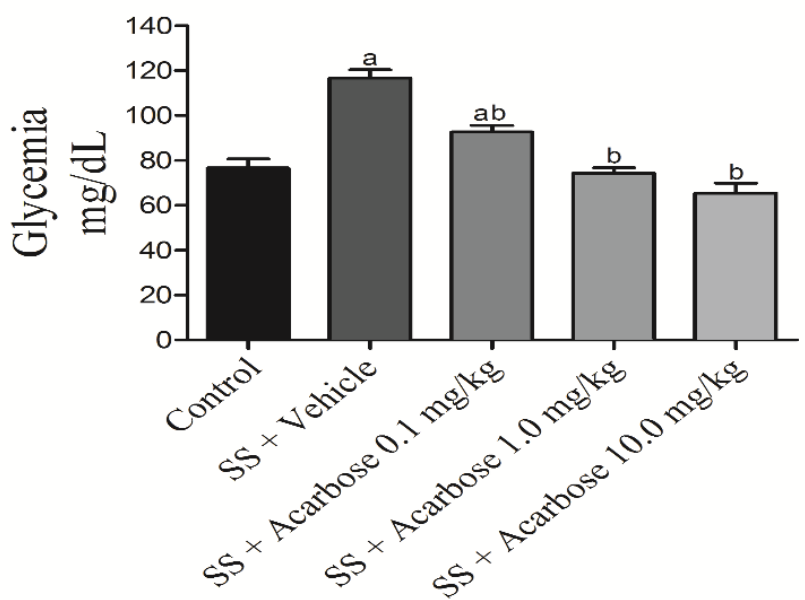

Figure 2. Effect of the acute administration (oral gavage) of soluble starch $1000 \mathrm{mg} / \mathrm{kg}$ (SS) plus acarbose on glycemia in 15 -h fasted rats. The blood glucose concentrations were evaluated at $30 \mathrm{~min}$ after the administration of SS plus vehicle or SS plus acarbose $(0.1$, 1.0 and $10.0 \mathrm{mg} / \mathrm{kg}$ ). The control group received oral (gavage) vehicle. The results are presented as mean \pm standard error of the mean. $n=6$ for each group. NewmanKeuls multiple comparison test. ${ }^{\mathrm{a}} \mathrm{p}<0.05$ when compared with control group; ${ }^{b} p<0.05$ when compared with $\mathrm{SS}+$ vehicle group.

Because acarbose prevent $100 \%$ the elevation of glycemia we also express the results as percent of effect in comparison with acarbose. Thus, the percent of reduction in the elevation of glycemia after the administration of soluble starch in the groups $\mathrm{SS}+$ GM $2.5 \mathrm{mg} / \mathrm{kg}$, SS + GM $5.0 \mathrm{mg} / \mathrm{kg}$, SS + GM 7.5 $\mathrm{mg} / \mathrm{kg}, \mathrm{SS}+\mathrm{GM} 10.0 \mathrm{mg} / \mathrm{kg}$ were $21.8 \%, 28.8 \%$, $25.4 \%$, and $20 \%$, respectively.

Since GM $(2.5 \mathrm{mg} / \mathrm{kg}, 5.0 \mathrm{mg} / \mathrm{kg}, 7.5 \mathrm{mg} / \mathrm{kg}$, and $10.0 \mathrm{mg} / \mathrm{kg})$ decrease $(\mathrm{P}<0.05)$ the intensity of elevation of glycemia promoted by soluble starch, the experiments described in the Figure $3 \mathrm{~A}$ were repeated again with lower $(0.1 \mathrm{mg} / \mathrm{kg}$ and $1.0 \mathrm{mg} / \mathrm{kg})$ and higher $(100.0 \mathrm{mg} / \mathrm{kg})$ doses of GM.

As shown in Figure 3B, the dose of $100.0 \mathrm{mg} / \mathrm{kg}$, but not the doses of $1.0 \mathrm{mg} / \mathrm{kg}$, and $0.1 \mathrm{mg} / \mathrm{kg}$, decrease $(\mathrm{P}<0.05)$ the elevation of glycemia promoted by soluble starch. The percent of reduction in the elevation of glycemia after the administration of soluble starch in the groups SS + GM $0.1 \mathrm{mg} / \mathrm{kg}$, SS $+\mathrm{GM} 1.0 \mathrm{mg} / \mathrm{kg}$, and SS + GM $100.0 \mathrm{mg} / \mathrm{kg}$ in comparison with SS + acarbose (100\%) were $0 \%$, $0 \%$, and $29.90 \%$, respectively. 


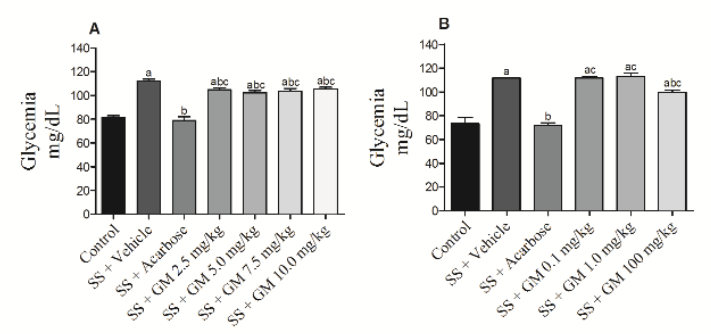

Figure 3. Effect of the acute administration (gavage) of vehicle (Control), soluble starch $1000 \mathrm{mg} / \mathrm{kg}$ (SS) plus vehicle, SS plus acarbose $10.0 \mathrm{mg} / \mathrm{kg}$, and SS plus Glycine $\max (\mathrm{GM})$ in the doses of 2.5, 5.0, 7.5 and $10.0 \mathrm{mg} / \mathrm{kg}$ (Fig. 3A) or GM 0.1, 1.0 and $100 \mathrm{mg} / \mathrm{kg}$ (Fig. 3B) in 15-h fasted rats. The glycemia was evaluated at $30 \mathrm{~min}$ after the administration of SS. The results are presented as mean \pm standard error of the mean. $n=5$ for each group. NewmanKeuls multiple comparison test. ${ }^{\mathrm{a}} \mathrm{p}<0.05$ when compared with control group; ${ }^{b} \mathrm{p}<0.05$ when compared with $\mathrm{SS}+$ vehicle group; ${ }^{c} \mathrm{p}<0.05$ when compared with $\mathrm{SS}+$ acarbose group.

\section{DISCUSSION}

An effective strategy for pre diabetes and type 2 diabetes treatments is the inhibition of intestinal $\alpha$ glucosidase. In this context, acarbose inhibits $\alpha$ glucosidase from brush border of the small intestine and slows carbohydrate digestion retarding intestinal absorption and thereby reducing postprandial hyperglycemia ${ }^{18}$. However, the undigested carbohydrates are fermented by colonic bacteria causing abdominal distention, flatulence, meteorism and diarrhea. Due to this side effect it is common the abandonment of treatment ${ }^{19}$.

Considering that in Brazil there is not another antidiabetic drug with ability to slow intestinal absorption, the possibility of using new compounds instead acarbose has been investigated.

In fact there are many in vitro studies showing inhibition of $\alpha$-glucosidase by isoflavones from plants $^{20-22}$. However, there is absence of in vivo studies demonstrating antihyperglycemic properties of these compounds.

Furthermore, as we previously demonstrated ${ }^{23-25}$ nondiabetic rats represents a suitable pre-clinical model to investigate the impact of oral carbohydrates on post prandial glycemia.

Thus, by using this rat model we investigate if dried extracts of GM could reduce the elevation of glycemia promoted by oral ingestion of soluble starch.

To the best of our knowledge we demonstrate for the first time the antihyperglycemic properties of
GM from in vivo experiments, i.e., the oral administration of GM $(2.5 \mathrm{mg} / \mathrm{kg}, 5.0 \mathrm{mg} / \mathrm{kg}, 7.5$ $\mathrm{mg} / \mathrm{kg}, 10.0 \mathrm{mg} / \mathrm{kg}$ and $100.0 \mathrm{mg} / \mathrm{kg}$ ) decrease $(\mathrm{P}<0.05)$ the intensity of elevation of glycemia promoted by soluble starch (Fig. 3A and 3B).

Thus, in agreement with several studies that demonstrated antidiabetic properties to $\mathrm{GM}^{7-13}$ we can conclude that isoflavones from dried extracts of GM show acute antihyperglycemic effect.

The difference from our results and several studies showing antidiabetic properties for GM is the fact that those evaluations were done after chronic treatment and our evaluation involve acute effects of GM on post prandial glycemia elevation after an oral overload of soluble starch.

Thus we concluded that the antidiabetic potential of GM also include acute effects preventing the elevation of post prandial glycemia.

\section{ACKNOWLEDGMENTS}

This study received funding from Program of Support for Excellence Centers (PRONEX)/Araucaria Foundation.

\section{CONFLICTS OF INTEREST}

The authors declare that they have no conflicts of interest.

\section{REFERENCES}

1. Mezei O, Banz WJ, Steger RW, Peluso MR, Winters TA, Shay N. Soy isoflavones exert antidiabetic and hypolipidemic effects through the PPAR pathways in obese Zucker rats and murine RAW 264.7 cells. J Nutr. 2003;133(5):1238-43.

2. Ricketts ML, Moore DD, Banz WJ, Mezei O, Shay NF. Molecular mechanisms of action of the soy isoflavones includes activation of promiscuous nuclear receptors. A review. J Nutr Biochem. 2005;16(6):321-30.

3. Babu PV, Liu D, Gilbert ER. Recent advances in understanding the anti-diabetic actions of dietary flavonoids. J Nutr Biochem. 2013;24(11):1777-89.

4. Tsugane S, Sawada N. The JPHC study: design and some findings on the typical Japanese diet. Jpn J Clin Oncol. 2014;44(9):777-82.

5. Wang Q, Ge X, Tian X, Zhang Y, Zhang J, Zhang P. Soy isoflavone: The multipurpose phytochemical (Review). Biomed Rep. 2013;1(5):697-701.

6. Guo TL, Wang Y, Xiong T, Ling X, Zheng J. Genistein modulation of streptozotocin diabetes in male $\mathrm{B} 6 \mathrm{C} 3 \mathrm{~F} 1$ mice can be induced by diet. Toxicol Appl Pharmacol. 2014;280(3):455-66. 
7. Malarde L, Groussard C, Lefeuvre-Orfila L, Vincent S, Efstathiou T, Gratas-Delamarche A. Fermented soy permeate reduces cytokine level and oxidative stress in streptozotocin-induced diabetic rats. J Med Food. 2015;18(1):67-75.

8. Mueller NT, Odegaard AO, Gross MD, Koh WP, Yu MC, Yuan JM, et al. Soy intake and risk of type 2 diabetes in Chinese Singaporeans [corrected]. Eur $J$ Nutr. 2012;51(8):1033-40.

9. Talaei M, Pan A. Role of phytoestrogens in prevention and management of type 2 diabetes. World J Diabetes. 2015;6(2):271-83.

10. Zimmermann C, Cederroth CR, Bourgoin L, Foti M, Nef S. Prevention of diabetes in $\mathrm{db} / \mathrm{db}$ mice by dietary soy is independent of isoflavone levels. Endocrinology. 2012;153(11):5200-11.

11. Gilbert ER, Liu D. Anti-diabetic functions of soy isoflavone genistein: mechanisms underlying its effects on pancreatic beta-cell function. Food Funct. 2013;4(2):200-12.

12. Curtis PJ, Sampson M, Potter J, Dhatariya K, Kroon PA, Cassidy A. Chronic ingestion of flavan-3-ols and isoflavones improves insulin sensitivity and lipoprotein status and attenuates estimated 10-year CVD risk in medicated postmenopausal women with type 2 diabetes: a 1-year, double-blind, randomized, controlled trial. Diabetes Care. 2012;35(2):226-32.

13. Genovese MI, Davila J, Lajolo FM. Isoflavones in Processed Soybean Products from Ecuador. Braz Arch Bio Technol. 2006; 49 (5): 853-59.

14. Lee DS, Lee SH. Genistein, a soy isoflavone, is a potent alpha-glucosidase inhibitor. FEBS Lett. 2001;501(1):84-6.

15. Bergmeyer HU, Bernt E. 1974. Determination of glucose with glucose oxidase and peroxidase. In Methods of Enzymatic Analysis, Bergmeyer HU (ed.). Academic Press: Weinhein, London; 1205-1215.

16. Kim JH, Kang MJ, Choi HN, Jeong SM, Lee YM, Kim JI. Quercetin attenuates fasting and postprandial hyperglycemia in animal models of diabetes mellitus. Nutr Res Pract. 2011;5(2):107-11.

17. DiNicolantonio JJ, Bhutani J, O'Keefe JH. Acarbose: safe and effective for lowering postprandial hyperglycaemia and improving cardiovascular outcomes. Open Heart. 2015;2(1):e000327.

18. Neuser D, Benson A, Bruckner A, Goldberg RB, Hoogwerf BJ, Petzinna D. Safety and tolerability of acarbose in the treatment of type 1 and type 2 diabetes mellitus. Clin Drug Investig. 2005;25(9):579-87.

19. Choi CW, Choi YH, Cha MR, Yoo DS, Kim YS, Yon GH, Hong KS, Kim YH, Ryu SY. Yeast $\alpha$-glucosidase inhibition by isoflavones from plants of leguminosae as an in vitro alternative to acarbose. J Agric Food Chem. 2010; 58(18): 9988-93.

20.Ademiluyi $A^{1}{ }^{1}$, Oboh $\mathrm{G}$. Soybean phenolic-rich extracts inhibit key-enzymes linked to type 2 diabetes ( $\alpha$-amylase and $\alpha$-glucosidase) and hypertension (angiotensin I converting enzyme) in vitro. Exp Toxicol Pathol. 2013;65(3): 305-9.

21. Benalla W, Bellahcen S, Bnouham M. Antidiabetic medicinal plants as a source of alpha glucosidase inhibitors. Curr Diabetes Rev. 2010; 6(4): 247-54.

22. Galende SB, Neto OCO, Santos LF, Peicher MV, Souza HM, Bazotte RB. Glucose administration inhibits the hepatic activation of gluconeogenesis promoted by insulin-induced hypoglycemia. Braz Arch Biol Technol. 2009;52(4): 849-54.

23. Galletto R, Siqueira VLD, Ferreira EB, Oliveira AJB, Bazotte RB. Absence of antidiabetic and hypolipidemic effect of Gymnema sylvestre in non-diabetic and alloxan-diabetic rats. Braz Arch Biol Technol. 2004; 47 (4): 545-51.

24. Sybuia MF, Guilhermetti M, Mangolim CS, Bazotte RB, Matioli G. Impact of cyclodextrins on postprandial glycemia: evaluation in experimental animal model using the real-time continuous glucose monitoring system. J Med Food. 2015;18(6): 625-30.

Received: February 05, 2016; Accepted: April 07, 2016. 